\title{
A Systematic Review of the Drug: Panax ginseng
}

\begin{abstract}
Received:
01.03.2019

Accepted:

25.03.2019

Keywords

Panax ginseng;

Immunomodulat

or; Anaemia;

Diabetes.
\end{abstract}

\author{
Sukhpreet Kaur*, Sachin Sharma \\ Sri Sai College of Pharmacy, Manawala, Amritsar-143115, Punjab, India \\ Address for Correspondence: Sukhpreet Kaur
}

ABSTRACT: Panax ginseng is a plant of family Araliaceae is generally known as Asian ginseng. Panax is derived from panacea, which means "all healing", The Plant is found extensively in Korea, Russia, and china and cultivated on a large commercial scale in japan, Canada, and united state. The main active components of Panax ginseng are ginsenosides, and other constituents are Panaxosides and chikusetsu saponins. It is also used in the treatment of anaemia, Diabetes as immunomodulator, in liver and skin cancer. Ginseng may improve thinking processes and cognition. Panax ginseng is a traditional herbal medicine that has been used therapeutically for more than 2000 years. (C) 2019 iGlobal Research and Publishing Foundation. All rights reserved.

Cite this article as: Kaur, S.; Sharma, S. A Systematic Review of the Drug: Panax ginseng. Indo Global J. Pharm. Sci., 2019; 9(2Suppl.): 154. DOI: http://doi.org/10.35652/IGJPS.2019.92S52.

Indo Global Journal of Pharmaceutical Sciences( ISSN 2249 1023; CODEN- IGJPAI; NLM ID: 101610675) indexed and abstracted in CrossRef (DOI Enabling), UGC CARE Journal List, EMBASE(Elsevier), National Library of Medicine (NLM) Catalog, ResearchGate, Publons, CAS (ACS), Index Copernicus, Google Scholar and many more. For further details, visit http://iglobaljournal.com

This is a special issue as an outcome of 'RAPSCON-2019' sponsored by APTI and organized by Sri Sai College of Pharmacy, Manawala, Amritsar, Punjab, India. Relaxation offered in journal format. 